\title{
Myelin Basic Protein: A Component of Circulating Immune Complexes in Multiple Sclerosis
}

\author{
Mrinal K. Dasgupta*, Ingrid Catz**, Kenneth G. Warren $\dagger$, Thomas A. McPherson**, \\ John B. Dossetor*, Patrick R. Carnegie**
}

SUMMARY: Myelin basic protein (MBP) is an antigenic component of circulating immune complexes (CIC) in patients with multiple sclerosis (MS). Immune complexes were isolated from the sera by adsorption to Raji cells and then acid eluted. Final identification of MBP from Raji eluates was done by sodium dodecyl sulfate-polyacrylamide gel electrophoresis (SDS-PAGE) followed by MBP radioimmunoassay (RIA) of gel eluates and by an immunoblot technique.

RÉSUMÉ: Les données recueillies ont permis d'établir que la protéine basique de la myéline (MBP) est présente dans les complexes immuns circulants $(\mathrm{CIC})$ de certains malades atteints de sclérose en plaques. Ces complexes ont été isolés du sérum par adsorption sur cellules de Raji et par élution en milieu acide. L'identification finale de la MBP a été complétée par radioimmunoassay et par une technique "immunoblot"' après électrophorèse en gel de polyacrylamide-dodecyl de sodium (SDS-PAGE).

Can. J. Neurol. Sci. 1983; 10:239-243

Multiple sclerosis (MS) continues to be a disease of unknown etiology. Autoimmunity is postulated, involving an antigen of myelin or oligodendrocytes, or alternatively some form of viral or other infective process (Paterson, 1978). The autoimmunity hypothesis is supported by evidence form experimental allergic encephalomyelitis (EAE) and a relapsing form of EAE. These are useful but not exactly similar experimental models of MS (Raine et al, 1974; McFarlin et al, 1975; Gutstein \& Cohen, 1978). Many clinical investigators have sought to implicate myelin basic protein (MBP), the causative antigen of EAE, in the pathogenesis of MS. MBP has been identified and quantitated in the cerebrospinal fluid (CSF) of patients with active demyelination, including MS (McPherson et al, 1972; Cohen et al, 1976; Whitaker, 1977). Antibodies to MBP have been identified in patients with MS (Panitch et al, 1980). Cellular immunity to MBP has been identified in MS patients (Lisak et al, 1977). Several laboratories have shown that circulating immune complexes (CIC) occur in serum of patients with MS though no specific antigen was reported (Tachovsky et al, 1976; Jacques et al, 1977; Goust et al, 1978; Deicher et al, 1980; Jans et al, 1980; Schocket et al, 1980; Trouillas et al, 1980; Noronha et al, 1981). Using the Raji cell radioimmunoassay (Raji-RIA) we reported data on the prevalence of CIC In 254 MS patients, (Dasgupta et al, 1982). In this report we present observations demonstrating that MBP was found to be an antigenic component in some CIC isolated from sera of some MS patients.

\section{Patients \& Materials}

Twenty-two serum samples were obtained from 19 MS patients. Control sera were collected from 3 patients with virus encephalitis, 2 patients with Guillain-Barré syndrome, 4 patients with active systemic lupus erythematosus, 2 patients with subacute bacterial endocarditis, and 1 patient with myasthenia gravis. Clinically, MS and control patients were free from any evidence of ongoing infection. Neurological diagnosis of MS patients was made according to criteria of Rose et al. (1976). Serum samples were collected, coded and stored at $-70^{\circ} \mathrm{C}$. These were all tested under blind control.

\section{Methods}

a) Raji-Radioimmunoassay (Raji-RIA) for Immune Complexes

Serum samples were analyzed for CIC by Raji-RIA as originally described by Theofilopoulos et al. (1976) except that 8-10 normal sera were included in each run and mean and standard deviations (S.D.) were determined for each assay. Results were expressed as S.D. units above the normal mean. Values greater than 2 S.D. units were considered abnormal (Johny et al. 1981).

\section{b) Acid elution of immune complexes from Raji cells}

Complexes present in MS sera were eluted from Raji cells with isotonic citrate buffer at $\mathrm{pH} 2.8-3.2$ (Theofilopoulos et al.

From the Department of Medicine (Nephrology and Clinical Immunology*. Neurology ${ }^{\dagger}$ ). University of Alberta and the Cross Cancer Institute**. Edmonton. Alberta.

Received April 14. 1983. Accepted in revised form September 13, 1983.

Reprint requests to: M.K. Dasgupta, M.D., Room 1046. University of Alberta Hospital. Edmonton. Alberta. Canada. T6G 2 B7. 
1978). Briefly, $40 \times 10^{6}$ Raji cells were incubated at $37^{\circ} \mathrm{C}$ for 45 minutes with $200 \mu$ l of test serum and were then washed three times. Washed Raji cells were then incubated for 7 minutes in freshly prepared isotonic citrate buffer containing $1 \% \mathrm{BSA}(\mathrm{pH}$ 2.8-3.2). Cells were then centrifuged at $500 \mathrm{~g}$ for 7 minutes and supernatants were collected, re-coded and passed on for further characterization by gel electrophoresis.

\section{c) Characterization of $\mathrm{MBP}$ in Acid Eluates from Raji Cells}

i) SDS Polyacrylamide Gel Electrophoresis (PAGE) of Raji Acid Eluates: SDS-PAGE was performed by a modified method of Carson et al, 1978. Basically, $10 \mu$ l of the acid eluates were mixed with $90 \mu \mathrm{l}$ of $0.01 \mathrm{M}$ phosphate buffer containing $1 \%$ SDS and $10 \mu \mathrm{l}$ each betamercaptoethanol (BME), glycerol and bromphenol blue and boiled for $90 \mathrm{sec}$. The samples were then underlayered on $10 \%$ polyacrylamide tube gels and run at $8 \mathrm{mAmps}$ per gel for four hours, at room temperature. After electrophoresis, the gels were stained in $0.1 \%$ Coomassie blue and excess stain was then removed by diffusion, using several changes of $10 \%$ acetic acid.

After destaining, the gels were sliced into $3 \mathrm{~mm}$ sections. Each slice was macerated and extracted by incubation in $1.5 \mathrm{ml}$ $\mathrm{T}_{3}$ buffer $(0.2 \mathrm{M}$ Tris, $1 \%$ Triton $\times 100,0.1 \%$ Trasylol, $\mathrm{pH} 7.2)$ for 1 hour at $37^{\circ} \mathrm{C}$ and overnight at room temperature. Duplicate $0.5 \mathrm{ml}$ aliquots were subjected to MBP RIA.

ii) Radioimmunoassay (RIA) for Myelin Basic Protein (MBP RIA): This was done by following a modified technique of the silica gel assay (Hsiung et al, 1978). Briefly, $0.5 \mathrm{ml}$ of the $\mathrm{T}_{3}$ buffer eluate from each gel slice was incubated with $0.3 \mathrm{ml}$ normal rabbit serum, $0.1 \mathrm{ml}$ concentrated $(10 \mathrm{x}) \mathrm{T}_{3}$ buffer and antibody to MBP to final dilution of $1: 1500$. After a 24 hour incubation at $4^{\circ} \mathrm{C},{ }^{125} \mathrm{I}-\mathrm{MBP}$ was added $(0.2 \mathrm{ng}-25,000 \mathrm{cpm})$ and the incubation was continued overnight $\left(4^{\circ} \mathrm{C}\right)$. The reaction was stopped by the addition of $0.5 \mathrm{ml}$ of $16 \mathrm{~g} / 100 \mathrm{ml}$ silica gel and the results were expressed as percentage bound to antibody (nonspecific binding subtracted).

Antibody to human MBP was raised in white New Zealand female rabbits (Palfreyman et al, 1978 and J.N. Whitaker, 1975). MBP was isolated from human brain (Diebler et al, 1972) and iodinated by the chloramine-T method (Hunter and Greenwood, 1968, as used by Hsuing et al, 1978); a fresh preparation of ${ }^{125}$ I-MBP being prepared at least every 4 weeks.

The silica gel RIA can detect as little as $1 \mathrm{ng}$ of $\mathrm{MBP} / \mathrm{ml}$ of CSF. There was negligible cross-reactivity with lysozyme, histones and EAE nonapeptide (Beckman). MBP or its fragments were detected, according to their molecular weights, in 3 different positions: (a) Component I = "MBP" - molecular wt 18,000, (b) Component II = "fragments of MBP" - molecular wt $<18,000$ and, (c) Component III = "high molecular wt MBP" - molecular wt approximately 50,000. Total inhibition, as well as inhibition associated with each of the three particular locations on the gels was computed, and the results were expressed as nanograms of MBP equivalents per $\mathrm{ml}$ ( $\mathrm{ng} \mathrm{MBP} \mathrm{eq} / \mathrm{ml}$ ).

iii) Immunoblot followed by ELISA: An immunoblot technique was also used to demonstrate the presence of MBP in CIC. The Raji eluates were applied to a $14 \%$ polyacrylamide slab gel, containing 1\% SDS, and after electrophoresis for 12 hours (5 mAmps/gel), the proteins were transferred to a nitrocellulose (NC) paper (Carnegie et al, 1983). The NC paper was probed with the same rabbit anti-MBP also used in the MBP-RIA and in turn the antibody was detected with an anti-rabbit alkaline phosphatase (Mason et al, 1978). This immunoblot technique is capable of detecting as little as $1.25 \mathrm{ng} \mathrm{MBP/well,} \mathrm{which} \mathrm{translates}$ into $7.5 \mathrm{ng} \mathrm{MBP} / \mathrm{ml}$ of acid eluate.

\section{d) Preparation of In Vitro MBP-Anti-MBP Complexes}

A constant amount of antibody (rabbit antiserum to MBP at 1/150 dilution) was added to increasing amounts of ${ }^{125} \mathrm{I}$-MBP until the zone of equivalence was identified ( $40 \mathrm{ng} / \mathrm{ml}$ of MBP). Complexes thus formed between anti-MBP and various amounts of unlabelled MBP were added to NHS (30 min at $37^{\circ} \mathrm{C}$ ) and incubated with Raji cells for absorption and elution studies.

\section{Results}

Serum samples from MS and control population were assayed for the presence of immune complexes by Raji RIA and acid eluates from Raji cells were further analyzed for MBP (Tables 1 and 2).

Twenty-two serum samples from 19 MS patients (Table 1) were grouped according to their clinical status: relapse (7), progressive disease (6), and in remission or stable phases (9). Fifteen of 22 MS samples were CIC positive (>2 SD units): 6 of 7 samples from patients in relapse, 3 of 6 samples from patients with chronic progressive disease and 6 of 9 samples from patients in remission or with stable disease. Eleven of the 22 Raji eluates were MBP positive (>1 ng MBP equivalents $/ \mathrm{ml}$ ): 3 of 7 samples

Table 1: Raji CIC and SDS-PAGE followed by MBP-RIA in Raji Eluates from MS Patients

\begin{tabular}{|c|c|c|c|c|c|}
\hline \multirow{2}{*}{$\begin{array}{l}\text { Sample Disease Status } \\
\text { No. }\end{array}$} & \multirow{3}{*}{$\begin{array}{c}\begin{array}{c}\text { Raji ClC** } \\
\text { (SD Units) }\end{array} \\
8.6\end{array}$} & \multicolumn{3}{|c|}{ MBP Components } & \multirow{2}{*}{$\begin{array}{l}\Sigma M B P^{*} \\
\text { ng eq/ml }\end{array}$} \\
\hline & & \multicolumn{3}{|c|}{ (ng eq/ml) } & \\
\hline 1 & & 0 & 19 & 14 & 33 \\
\hline 2 & 8.5 & 0 & 0 & 0 & 0 \\
\hline 3 & 6.4 & 1 & 0 & 3 & 4 \\
\hline Relapse & 5.1 & 0 & 1 & 0 & 1 \\
\hline 5 & 4.7 & 14 & 9 & 1 & 24 \\
\hline 6 & 4.4 & 1 & 0 & 0 & 1 \\
\hline 7 & 0.1 & 0 & 1 & 0 & 1 \\
\hline 8 & 4.4 & 15 & 0 & 0 & 15 \\
\hline 9 & 4.4 & 0 & 0 & 0 & 0 \\
\hline Progressive & 3.8 & 0 & 3 & 0 & 3 \\
\hline 11 & 1.8 & 2 & 0 & 4 & 6 \\
\hline 12 & 0.8 & 0 & 0 & 1 & 1 \\
\hline 13 & 0.1 & 0 & 0 & 0 & 0 \\
\hline 14 & 8.4 & 21 & 0 & 0 & 10 \\
\hline 15 & 7.3 & 19 & 0 & 0 & 19 \\
\hline Remission & 6.0 & 0 & 0 & 0 & 0 \\
\hline 17 & 2.9 & 24 & 0 & 0 & 24 \\
\hline 18 & 2.4 & 1 & 2 & 1 & 4 \\
\hline 19 & 0.1 & 0 & 0 & 0 & 0 \\
\hline 20 & 3.7 & 0 & 0 & 0 & 0 \\
\hline Stable & 0.3 & 1 & 0 & 2 & 3 \\
\hline 22 & 0.1 & 0 & 0 & 0 & 0 \\
\hline
\end{tabular}

${ }^{* *}$ CIC positive: $\geqslant 2$ SD units

* MBP-positive: $>1.0 \mathrm{ng} \mathrm{eq} / \mathrm{ml}$

$\Sigma$ sum of 3 MBP components 
from patients in acute relapse, 3 of 6 samples from those with progressive disease and 5 of 9 patients in remission or in stable condition.

Of the 15 CIC positive sera, 9 were also positive for MBP, the remaining 6 being either borderline $(1 \mathrm{ng} / \mathrm{ml})$ or negative. Of the remaining $7 \mathrm{CIC}$ negative sera, only 2 were $\mathrm{MBP}$ positive. Immune complexes containing MBP were detected in both active and inactive phases of the disease, but the number of samples is clearly too small to correlate the presence or absence of MBP in CIC with disease activity. One MS patient with immune complexes containing MBP is illustrated in Fig. $1 \mathrm{~A}$ and another MS patient who was CIC and MBP negative is illustrated in Fig. 1B.

Six patients with neurological diseases and six with nonneurological diseases were similarly studied for the presence of MBP-containing CIC in Raji cell eluates (Table 2). Of the 6 patients with neurological disease, only the patient with myasthenia gravis was $\mathrm{CIC}$ positive. The immune complexes of this patient did not contain MBP. One of 2 patients with herpes virus encephalitis, although $\mathrm{CIC}$ negative, had detectable MBP. The remaining 4 patients were both $\mathrm{CIC}$ and MBP negative.

High levels of CIC occurred in all 6 patients with nonneurological disease (4 patients with SLE and 2 patients with SBE). MBP was not detected in any of these complexes (Table 2).

Table 2: Raji CIC and SDS-PAGE followed by MBP-RIA in Raji eluates from control patients

\begin{tabular}{lcc}
\hline \hline & $\begin{array}{c}\text { Raji ClC** } \\
\text { (SD units) }\end{array}$ & $\begin{array}{c}\text { MBP* } \\
\text { (ng eq/ml) }\end{array}$ \\
\hline
\end{tabular}

a) Neurologic controls:

1. Herpes virus encephalitis

2. Herpes virus encephalitis

3. Guillain Barré syndrome

4. Guillain Barré syndrome

5. Viral encephalitis

6. Myasthenia gravis

b) Non-neurologic controls:

1. Systemic lupus erythematosus

2. Systemic lupus erythematosus

3. Systemic lupus erythematosus

4. Systemic lupus erythematosus

5. Subacute bacterial endocarditis

6. Subacute bacterial endocarditis

$* *$ CIC positive: $\geqslant 2$ SD units

* MBP-POSITIVE: $>1.0 \mathrm{ng} \mathrm{eq} / \mathrm{ml}$

To confirm the specificity of the MBP assays another group of controls were studied exactly as described above by Raji cell acid elution followed by SDS-PAGE and MBP-RIA. These included (i) human MBP standards in different concentrations in $T_{3}$ and isotonic acid citrate buffer, (ii) in vitro prepared MBP-anti-MBP complexes and equivalent amount of "free" MBP, added to normal human serum (NHS), and (iii) supernatants of Raji cells $\left(40 \times 10^{6}\right)$ washed in RPMI medium. Some results from these controls are shown in Fig. 1.

The isotonic acid citrate buffer $(\mathrm{pH} 3.2)$ used to elute CIC from Raji cells does not alter the antigenicity of MBP because
MBP so treated migrates electrophoretically to the identical position observed for untreated standard MBP (see Fig. IC and 1D).

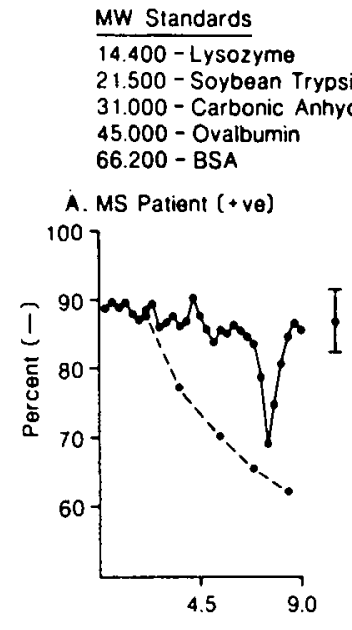

B. MS Patient $(-$ ve $)$

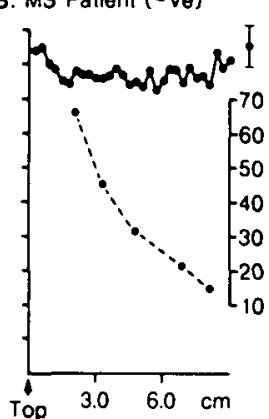

C. MBP Standard

D. MBP Standard (isotonic citrate buffer)
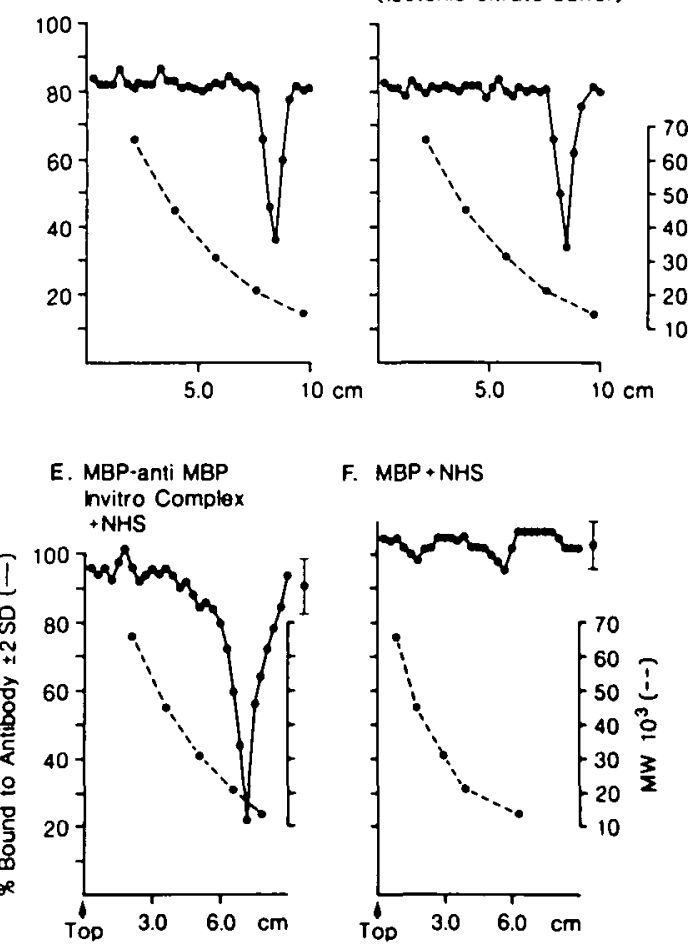

F. $M B P+N H S$

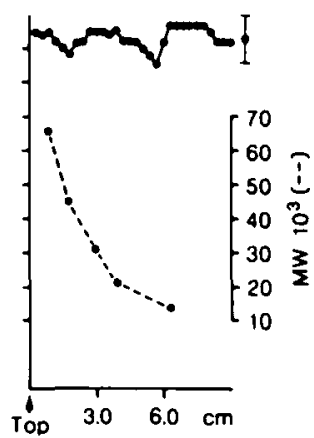

Figure 1 - Results of SDS-PAGE and MBP RIA: A) Raji eluates of a CIC positive $M S$ patient, B) Raji eluates of a CIC negative $M S$ patient, C) MBP standard (75 $\mathrm{ng} / \mathrm{ml})$ in $T_{3}$ buffer, D) MBP standard $(75 \mathrm{ng} / \mathrm{ml})$ is isotonic citrate buffer ( $p H 3.2)$, E) Raji eluates of in vitro prepared $M B P(88 \mathrm{ng} / \mathrm{ml})$ anti-MBP (3:I antigen/antibody ratio) complex in NHS. F) Raji eluates of the same amount of free $M B P(88 \mathrm{ng} / \mathrm{ml})$ in $N H S$

$M P B$ is shown as solid line (__ in relation to left ordinate. The molecular weight $(M W)$ standards simultaneously run. are shown as an interrupted line (.........) in relation to right ordinate. $M W$ markers used are identified at the top of the figure. The $M W$ of each component causing inhibition in the MBP-RIA can be determined by comparing the position of the inhibitory component with that of the $M W$ markers. In the examples shown here, all inhibitory components from the gel had similar MW's of about 18.000 . 
A definite component corresponding to 18,000 $\mathrm{MW}$ is detected in the Raji eluate from an in vitro prepared MBP-anti MBP complex (in 3:1 antigen excess) added to NHS (Fig. IE) while no inhibition is observed in a Raji eluate from an in vitro preparation of a mixture of the same amount of "free" MBP incubated in NHS (Fig. IF). This confirms that "free" MBP in NHS adsorbs poorly, if at all, to Raji cells and that the inhibitory component seen in Fig. IE belongs to the MBP engaged in the complex. Also, no trace of MBP activity was noted from acid eluates of Raji cell "washings" in RPMI medium (data not shown). This indicates the absence of other non-MBP inhibitory substances present on the Raji cell surfaces.

The previous results on acid eluates from MS patients were further confirmed by the immunoblot technique (Fig. 2). Raji eluates from 3 MS sera, which were positive for CIC (Table $1-$ \#8, \#15,\#17), show a definite band which comigrates with the MBP standard. No trace of MBP was detected in serum of a patient (Table 1-\#13) that was negative by RIA. Additionally, all serum samples were negative for free MBP by direct RIA.

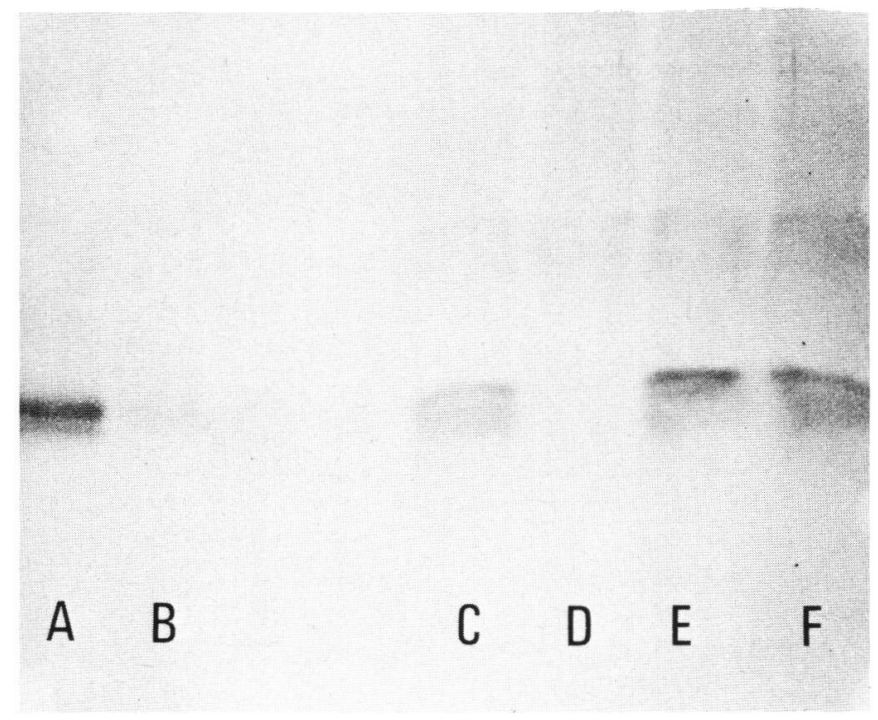

Figure 2 - Results of the immunoblot technique followed by ELISA: A $M B P$ standard ( $10 \mathrm{ng} / \mathrm{well}$ ), $B-M B P$ standard ( $\mathrm{ng} / \mathrm{we} / \mathrm{li}), C, E$ and $F-$ Three CIC positive, MBP positive samples (Table I-\#8, \#15, \#17), D - One CIC negative, MBP-RIA negative sample (Table I-\#13)

In the 3 CIC positive MBP-positive samples, a definite band is seen to comigrate with the MBP standard, while no such band is observed in the sample negative for both $C I C$ and $M B P$.

\section{Discussion}

The purpose of this study was to examine CIC from MS patients for the presence of MBP. This was accomplished by using Raji-RIA, elution of CIC from Raji cells with isotonic acid citrate buffer and subsequent analyses of the eluates by SDSPAGE and MBP-RIA. MBP was detected in CIC of 11 of $22 \mathrm{MS}$ sera and in 1 of 12 neurologic and other controls. However, we also noted that Raji eluates from some MS patients positive for $\mathrm{CIC}$ by Raji-RIA did not contain MBP, and that 2 Raji eluates from MS sera negative for CIC contained MBP. Also, Raji eluates from some MS patients did not contain either CIC or MBP.
Detection of MBP in Raji eluates of sera which were negative for CIC in the Raji RIA may be due to one or more of the following:

(i) presence of inhibitory serum substances other than MBP, as our assay for $\mathrm{MBP}$ is done by using a polyclonal rabbit antiserum to MBP. We believe this is unlikely because we have demonstrated a good correlation between MBP-RIA and immunoblot-ELISA results using the same polyclonal rabbit antiserum to MBP (Fig. 2).

(ii) "free" MBP (and not complexed MBP) in serum samples. This is unlikely because "free" MBP does not bind to Raji cells. Further, serum samples studied for presence of MBP by MBP-RIA were all negative.

(iii) presence of $\mathrm{CIC}$ containing immunoglobulins (Ig) other than $\operatorname{IgG}$ (e.g. $\operatorname{IgM}, \operatorname{Ig} A$, etc.). Non-IgG complexes could adsorb to Raji cells but would not be detected by the Raji-RIA technique as this test was done with ${ }^{125} \mathrm{I}$-anti-human IgG.

(iv) the increased sensitivity of SDS-PAGE followed by MBPRIA for detection of MBP as compared to the detection of CIC by the Raji RIA. This may explain why one patient with herpes virus encephalitis in our control population had detectable MBP but no detectable CIC. Thus, MBP containing immune complexes may not be specific for MS patients just as MBP in CSF is not found only in MS patients. Further studies are required to determine the frequency of MBP-containing CIC in demyelinating and non-demyelinating diseases of the human nervous system.

MBP in serum is fragmented by proteolytic enzymes and these fragments retain their antigenicity (Paterson 1976; Alvord et al, 1979). Soluble MBP fragments can form complexes of different lattice structure with anti-MBP and might exert immunoregulatory effects in MS (Paterson, 1982). Our findings that MBP and its fragments are present as antigenic materials in Raji cell acid eluates of CIC is in keeping with above observations except that we could also detect some large molecular fragments ( $\geqslant 50,000$ daltons) of MBP reactive materials (see Table 1 ). Large molecular weight MBP has been described previously; it was found to be present in CSF of some MS patients and not in 'non-MS' controls (Carson et al, 1978). The exact nature of this large molecular weight material, antigenically cross reactive with rabbit antisera to MBP is not known (Carson et al, 1978). It might represent a MBP polymer or MBP bound to other molecules which is detected by the polyclonal rabbit antisera to MBP.

In conclusion, we find MBP is an antigenic component of some CIC in sera of some MS patients. The significance of this observation in relation to disease pathogenesis or disease activity has not yet been clarified.

$M B P$ is the antigenic trigger of EAE. The presence of CIC in EAE (Koh et al, 1983; Paterson et al, 1982) and their possible immunoregulatory effect have been noted (Paterson et al, 1982). CIC containing MBP may therefore play a role in the development, immunoregulation or evolution of MS. It is also possible that detection of CIC containing MBP represents an epiphenomenon unrelated to the course of MS. There is a need for much further study of antigen specific complexes, such as CIC containing MBP, in MS patients, before their true significance is known.

\section{ACKNOWLEDGEMENTS}

This research was supported by the following agencies: Medical Research Council of Canada, Multiple Sclerosis Society of Canada, 
Friends of Edmonton MS Research Clinic. the Association of Canadian Travellers of Edmonton. Kidney Foundation of Canada and the Alberta Heritage Foundation for Medical Research (AHFMR).

Dr. P.R. Carnegie was a visiting scientist from La Trobe University. Melbourne. Australia. supported by the AHFMR. Dr. M.K. Dasgupta is a scholar of the AHFMR.

\section{REFERENCES}

Alvord, E.C., Hruby, S., Sires, L.R. (1979). Degradation of myelin basic protein by cerebrospinal fluid: preservation of antigenic determinants under physiological conditions. Ann. Neurol. 6:474-482.

Carnegie, P.R., Dowse, C.A., Linthicum, D.S. (1983). Antigenic determinant recognized by a monoclonal antibody to myelin basic protein. J. Neuroimmunol., (in press).

Carson, J.H., Barbarese, E., Braun. P.E., McPherson. T.A. (1978). Components of multiple sclerosis cerebrospinal fluid that are detected by radioimmunoassay for myelin basic protein. Proc. Natl. Acad. Sci. USA 75, 1976-1978.

Cohen, S.R., Herndon, R.M., McKhann. G.M. (1976). Radioimmunoassay of myelin basic protein in spinal fluid an index of active demyelination. New Engl. J. Med. 295: 1455-1457.

Dasgupta, M.K.. Warren, K.G., Johny, K.V., and Dossetor, J.B. (1982). Circulating immune complexes in multiple sclerosis: relation with disease activity. Neurology (Ny) 32: 1000-1004.

Deicher, H., Schwabedissen, H.M., Liman, W.. Baruth, B., Patzold. U., Haller, P. (1980). Immune complexes in cerebrospinal fluid and serum of patients with multiple sclerosis. In: Bauer, H.G., Poser, S., Ritter, G., eds. Progress in multiple sclerosis research. Verlag, Berlin: Springer, 200-206.

Diebler, G.E., Martenson, R.C., Kies, M.W. (1972). Large scale preparation of myelin basic protein from central nervous tissue of several mammalian species. Prep. Biochem. 2: 139-165.

Goust, J.M., Chenais, F., Carnes, J.E., Hames, C.G., Fudenbergh, H.H., Hogan, H.L. (1978). Abnormal T cell subpopulations and circulating immune complexes in the Guillain-Barre syndrome and multiple sclerosis. Neurology ( $\mathrm{Ny}$ ) 28: $421-425$.

Gutstein, H.S. and Cohen, S.R. (1978). Spinal fluid differences in experimental allergic encephalomyelitis and multiple sclerosis. Science 199, 301-303.

Hsiung, H.M., Wu, J., McPherson, T.A. (1978). Silica gel radioimmunoassay for myelin basic protein. Clin. Biochem. 11: 54-56.

Hunter, W.M., and Greenwood, F.C. (1962). Preparation of ${ }^{131}$ I labelled human growth hormone of high specific activity. Nature 195: 495-496.

Jacques, C., Davous, P., Baumann, N. (1977). Circulating immune complexes and multiple sclerosis. Lancet 2: 408.

Jans, H., Jersild, C., Taaning, E., Dybkjaer, E., Fog, T., Heltberg, A. (1980). The occurrence of immune complexes in patients with multiple sclerosis. In: Bauer, H.G., Poser, S., Ritter, G., eds. Progress in multiple sclerosis research. Verlag. Berlin: Springer, 195-199.

Johny, K.V., Dasgupta, M.K., Nakashima, S., Dossetor, J.B. (1981). Three polyethylene glycol dependent methods for the detection of circulating immune complexes in pathological sera: comparison with the Raji cell method. J. Immunol. Methods 40: 61-71.

Koh, S.C., Tsukada, N., Yanagisawa, N., Kunishita, T., Uemura, K. Taketomi, T. (1981). Mild encephalitogenic activity of basic proteinacidic lipid complex from myelin and detection of immune complexes in experimental allergic encephalomyelitis. J. Neuroimmunology 1: 69-80.
Lisak, R.P. and Zweiman. B. (1977). In vitro cell mediated immunity of cerebrospinal fluid lymphocytes to myelin basic protein in primary demyelinating disease. New Engl. J. Med. 297: 850-853.

Mason. D.Y., Sammons, R. (1978). Alkaline phosphatase and peroxidase for double immunoenzymatic labelling of culture constituents. J. Clin. Path. 31: 454-460.

McFarlin, D.E., Hsu, S.C.L., Slemenda, S.B., Chou, F.C.H. and Kibler. R.F. (1975). The immune response against myelin basic protein in two strains of rat with different genetic capacity to develop experimental allergic encephalomyelitis. J. Exp. Med. 141: 72-81.

McPherson, T.A.. Gilpin, A.. Seland, T.P. (1972). Radioimmunoassay of CSF for encephalitogenic basic protein. Can. Med. Assn. J. 107: 856-859.

Noronha, A.B.C., Antel. J.P., Roos, R.P.. Medof, E.M. (1981). Circulating immune complexes in neurologic disease. Neurology 31: 1402-1407.

Palfreyman, J.W., Thomas, G.T., Ratcliffe. J.G. (1978). Radioimmunoassay of human myelin basic protein in tissue extract. cerebrospinal fluid and serum and its clinical application to patients with head injury. Clin. Chem. Acta 82: 259.

Panitch, H.S., Hafler. D.A. Johnson. K.P. (1980). Antibodies to myelin basic protein in cerebrospinal fluid of patients with multiple sclerosis. In: Bauer, H.J., Poser, S.R., Ritter, G., Eds. Progress in Multiple Sclerosis Research. Springer-Verlag. Berlin. Heidelberg. New York. pp. 98-105.

Paterson. P.Y. (1976). Experimental autoimmune (allergic) encephalomyelitis: induction. pathogenesis and suppression. in Textbook of Immunopathology. (Second Edn) Meischer. P.A.. Muller-Eberherd. J.J. (eds). Grune \& Stratton. New York, Vol I, 179-213.

Paterson. P.Y. (1978). The demyelinating diseases: clinical and experimental studies in animals and man. In: Immunological Diseases, M. Santer, Ed., Little Brown Co., USA.. Vol. II. 1406-1419.

Paterson, P.Y., and Day, E.D. (1982). Current perspectives of neuroimmunologic diseases: MS and experimental allergic encephalomyelitis. Clin. Immunol. Rev 1: 581-697.

Raine, C.S., Snyder, D.H., Valsamis, M.P., Stone, S.H. (1974). Chronic experimental allergic encephalomyelitis in inbred guinea pigs: an ultrastructural study. Lab. Invest. 31: 369-380.

Rose, A.S., Ellison, G.W. Myers. L.W.. Tourtellotte, W.W. Criteria for the clinical diagnosis of multiple sclerosis. Neurology 1976: 26 (part 2): 20-22.

Schocket, A.L., Carr, R.I. , Hardtke, M.A. (1980). A comparison of ${ }^{125} 1$ $\mathrm{Clq}$ binding, Raji cell binding and lymphocytotoxic activity in multiple sclerosis. Clin. Immunol. Immunopathol. 17: 477-481.

Tachovsky, T.G., Lisak, R.P.. Koprowski, H.. Theofilopoulos, A.N.. Dixon, F.J. (1976). Circulating immune complexes in multiple sclerosis and other neurological diseases. Lancet 2: 997-999.

Theofilopoulos, A.N., Eisenberg. R.A., Dixon. F.J. (1978). Isolation of circulating immune complexes using Raji cells: separation of antigens from immune complexes and production of anti-serum. $J$. Clin. Invest. 61: 1570-1581.

Theofilopoulos, A.N., Wilson, C.B. and Dixon F.J. (1976). The Raji cell radioimmunoassay for detection of circulating immune complexes. J. Clin. Invest. 57: 169-182.

Trouillas, P.. Vincent, C.. Revillard. J.V. (1980). Clq binding circulating immune complexes in multiple sclerosis patients and their first degree relatives: a distinctive immunological feature between sporadic and familial cases. J. Clin. Lab. Immunol. 4: 77-81.

Whitaker, J.N. (1975). The antigenicity of myelin basic protein: production of antibodies to encephalitogenic protein with DNA-encephalitogenic protein complexes. J. Immunol. 114: 823-830.

Whitaker, J.N. (1977). Myelin encephalitogenic protein fragments in cerebrospinal fluid of persons with multiple sclerosis. Neurology 27: $911-920$. 